\title{
Pemberdayaan Kaum Bapa Masyarakat Pesisir Amurang Lopana Satu Untuk Mengembangkan Wisata Pantai dengan Pendekatan Holistik
}

\author{
Nelson Nainggolan*1, Dingse Pandiangan ${ }^{2}$ \\ ${ }^{1}$ Jurusan Matematika FMIPA Universitas Sam Ratulangi Manado Indonesia \\ ${ }^{2}$ Jurusan Biologi FMIPA Universitas Sam Ratulangi Manado Indonesia \\ *Penulis Korespondensi. Email: $\underline{\text { n-nelson@unsrat.ac.id }}$
}

\begin{abstract}
ABSTRAK
Program kemitraan masyarakat sangat penting untuk mendukung terlaksananya tugas pokok seorang Dosen yaitu pegabdian pada masyarakat. Analisis situasi pada tahun 2017 melalui kegiatan KKT118 diperoleh data bahwa desa Lopana Satu merupakan desa yang berada di tepi pantai yang potensial untuk dikembangkan menjadi daerah pariwisata. Desa ini masangat tertinggal dari segi penataan, pendidikan dan SDM. Oleh sebab itu perlu kemitraan untuk membina Desa ini untuk pengembangan potensi yang telah ada. Analisis situasi lainnya menunjukkan bahwa permasalahan keluarga kebanyakan karena Pendidikan, kesehatan jasmani dan rohani atau mental para Kaum Bapak di desa tersebut tidak maksimal untuk mencapai kesejahteraan keluarga. Kegiatan ini dilakukan secara bertahap dan berkesinambungan sampai diperoleh suatu Desa Sejahtera dan percontohan di Sulawesi Utara. Masyarakat diharapkan berkontribusi kepada pembangunan Desa dalam hal pendirian pantai indah dan sehat di Lopana Satu untuk mereka menyerahkan lahannya di daerah pantai yang terabaikan atau kepada pemerintah untuk di hias pantainya dengan menanam bibit buah buahan dan pohon yang bernilai ekonomis tinggi disertai tanaman hias. Tanaman hias dan obat tapak dara (Catharanthus roseus) sebagai tanaman penghias pantai dan sekaligus pendidikan obat herbal bagi masyarakat yang ada. Target kegiatan PKM ini adalah memberikan motivasi dan inovasi yang baru kepada masyarakat. Luarannya diitargetkan melalui kegiatan PKM ini ternyata bisa meningkatkan semangat para Kaum Bapa untuk memiliki pola hidup sehat mengurangi kemabukan dan minum minuman keras seperti cap tikus menjadi gaya hidup yang trampil dengan memperoleh beberapa keahlian sehingga rumah tangganya bahagia yang diawali dengan seorang ayah yang bijaksana. Target lainnya diharapkan menjadikan cikal bakal tradisi di masyarakat Lopada Satu Amurang Timur untuk membuka usaha wisata di pantai yang dibarengi dengan keindahannya. Luaran sampai tulisan ini masih sedang dilakukan pemeliharaan tanaman dan sudah diperoleh hasil pertandingan taman yang sangat menggembirakan semangat dan kebersamaan para apparat dan masyarakat yang ada.
\end{abstract}

Kata Kunci: Desa Sejahtera; Kaum Bapa; Holistik; Lopana Satu; Amurang

\section{PENDAHULUAN}

\section{Analisis Situasi}

Desa Lopana Satu masih berada di tepi pantai dan merupakan Desa yang baru terbentuk dan masih serba kurang perlu bantuan melalui kemitraan dengan kegiatan ini. Desa ini sangat tertinggal dari segi pendidikan, penataan dan sumberdaya manusia. Oleh sebab itu perlu kemitraan untuk membina Desa ini untuk pengembangan potensi yang telah ada. Hasil analisis situasi yang lain menunjukkan bahwa permasalahan keluarga kebanyakan karena kesehatan jasmani dan rohani para Kaum Bapa di desa tersebut kurang maksimal untuk mencapai kesejahteraan dan keamanan. Permasalahan prioritas yang harus ditangani adalah:

1. Banyaknya Kaum Bapa yang tidak mencukupi pendapatannya untuk menghidupi keluarganya atau banyaknya pengangguran

2. Banyaknya anak-anak yang putus sekolah atau malas sekolah karena ajaran atau didikan seorang Ayah atau Kaum Bapa yang menyatakan untuk apa capek-capek sekolah kerja aja cari makan dan sering hanya diajak membantu kerja sebagai nelayan saja.

3. Banyaknya angka perceraian atau ketidak cocokan dalam hubungan suami istri. 


\section{VIVABIO}

Jurnal Pengabdian Multidisiplin

4. Kurangnya penghayatan akan kasih karunia Tuhan bagi setiap keluarga yang merupakan karya ciptaan Tuhan untuk membentuk suatu keluarga yang saling mengasihi agar berkat Tuhan dilimpahkan bagi keluarga harmonis yng dengan sendirinya menjadi keluarga bahagia atau sejahtera.

Berdasarkan masalah di atas, maka perlu diadakan kegiatan pemberdayaan dan penyuluhan untuk meningkatkan kesadaran dan sekaligus mengarahkan warga desa Lopana Satu.

\section{Tujuan dan Manfaat Kegiatan}

Sesuai dengan rencana kegiatan, maka luaran yang dihasilkan atau ditargetkan dalam kegiatan pengabdian pada masyarakat ini adalah:

1. Pemberian bibit tanaman hias dan tanaman buah-buahan serta pohon ekonomis penghias pantai untuk modal masyarakat untuk mengembangkan Wisata Pantai

2. Melakukan perlombaan taman setelah pemberian bibit tanaman untuk dinilai pemeliharaan dan kegiatannya

3. Memberikan program revolusi mental dengan melakukan dorongan untuk banyak beribadah dan berdoa kepada Tuhan berupa materi dan strategi agar meningkatkan keharmonisan keluarga dengan membuat suatu pertemuan khusus bagi keluarga-keluarga muda.

4. Melakukan kegiatan Seminar dan Kebangunan Rohani yang pesertanya khusus pada Kaum Bapa supaya mereka dapat maksimal menceritakan maalah yang mereka hadapi dan diberikan strategi supaya mereka harmonis atau rujuk kembali (bagi yang sudah hampir atau bercerai).

\section{METODE PELAKSANAAN}

\section{Sasaran kegiatan}

Khalayak sasaran yang dituju adalah masyarakat Desa Lopana Satu dan sekitarnya, yang lebih difokuskan kepada Kaum Bapak dalam hal pemberdayaannya dan keharmonisan keluarganya.

\section{Lokasi kegiatan}

Kegiatan ini dilakukan di Desa Lopana Satu, Kecamatan Amurang Timur, Kabupaten Minahasa Selatan. Kegiatan penyuluhan dilaksanakan di dalam Gedung Posyandu Desa Lopana Satu.

\section{Metoda yang Digunakan:}

Kegiatan pengabdian ini dilaksanakan dalam bentuk kegiatan sosialisasi program di sekitar bulan April 2019 kepada Aparat Desa sekitar 20 orang dengan komposisi seperti Lampiran 1. Kemudian dilakukan penyuluhan kepada masyarakat bersama apparat bersamaan dengan pelaksanaan pertandingan sepak bola antar jaga (lingkungan) dilakukan selama dua kali pertemuan dengan jumlah peserta adalah sekitar 100 orang bersama aparat Desa dan pelaksana kegiatan.

Pada tahap berikutnya pelaksanaan pengadaan bibit tanaman oleh pelaksana bekerjasama dengan PPSDA Manado. dilaksanakan sekitar akhir Juni sampai Juli 2019. Tahap selanjutnya bibit tanaman hias dan buah buahan serta pohon -pohonan diberikan kepada masyarakat Lopana Satu secara merata perjaga atau per lingkungan yaitu pohon Gaharu 20 polibag, Pala 35 polibag, Matoa 35 polibag, Durian 40 polibag, Duku 35 polibag dan tanaman hias tapak dara. Bibit diberikan kepada masyarakat Lopana Satu yang terdiri dari 8 jaga mulai Jaga I, II, III, IV, V, VI, VII dan VIII. Jadi jumlah bibit tanaman yang dibagikan keseluruhan adalah pohon Gaharu 160 polibag, Pala 280 polibag, Matoa 280 polibag, Durian 320 polibag, Duku 280 polibag dan tanaman hias tapak dara tidak dihitung tapi bebas sesuai kebutuhan masyarakat.

Bibit Tanaman yang dibagikan dipelihara dulu untuk adaptasi datasi di daerah pantai yang panas. Selama adaptasi dilakukan penataan di lingkungan setiap jaga yang telah ditetapkan. Jumlah bibit tanaman yang bertahan tumbuh juga merupakan indikator kebersamaan dan motivasi setiap jaga pada penlilaian lomba taman Lopana satu. Adapun point penilaian taman seperti yang berikut Tabel 1 .

Tabel 1. Sususnan dan komponen penilaian pada Lomba Taman Lopana Satu 
VIVABIO

Jurnal Pengabdian Multidisiplin

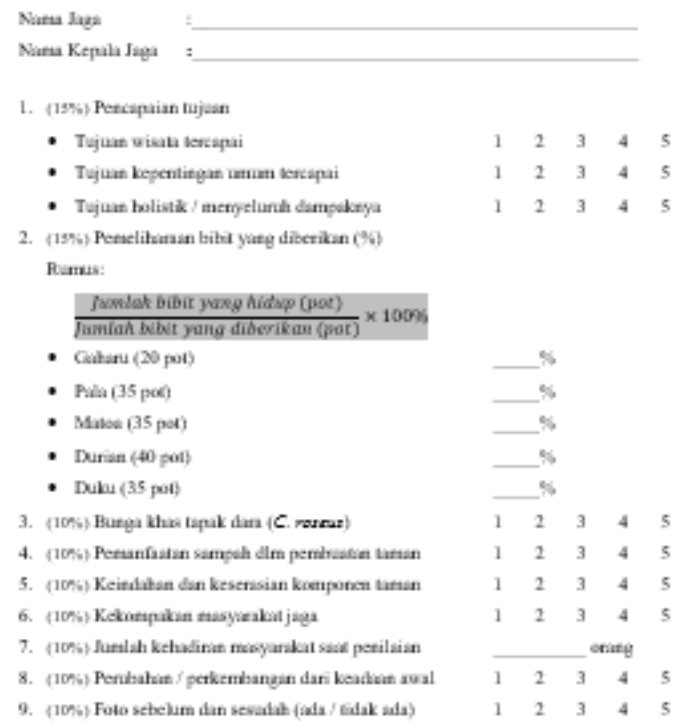

Perlombaan taman dilakukan pada tanggal 16-26 Agustus 2019. Dan terlihat aparat pengawas juga dari Kecamatan Amurang Timur serta Kepala Dinas Pariwisata (Gambar 3)
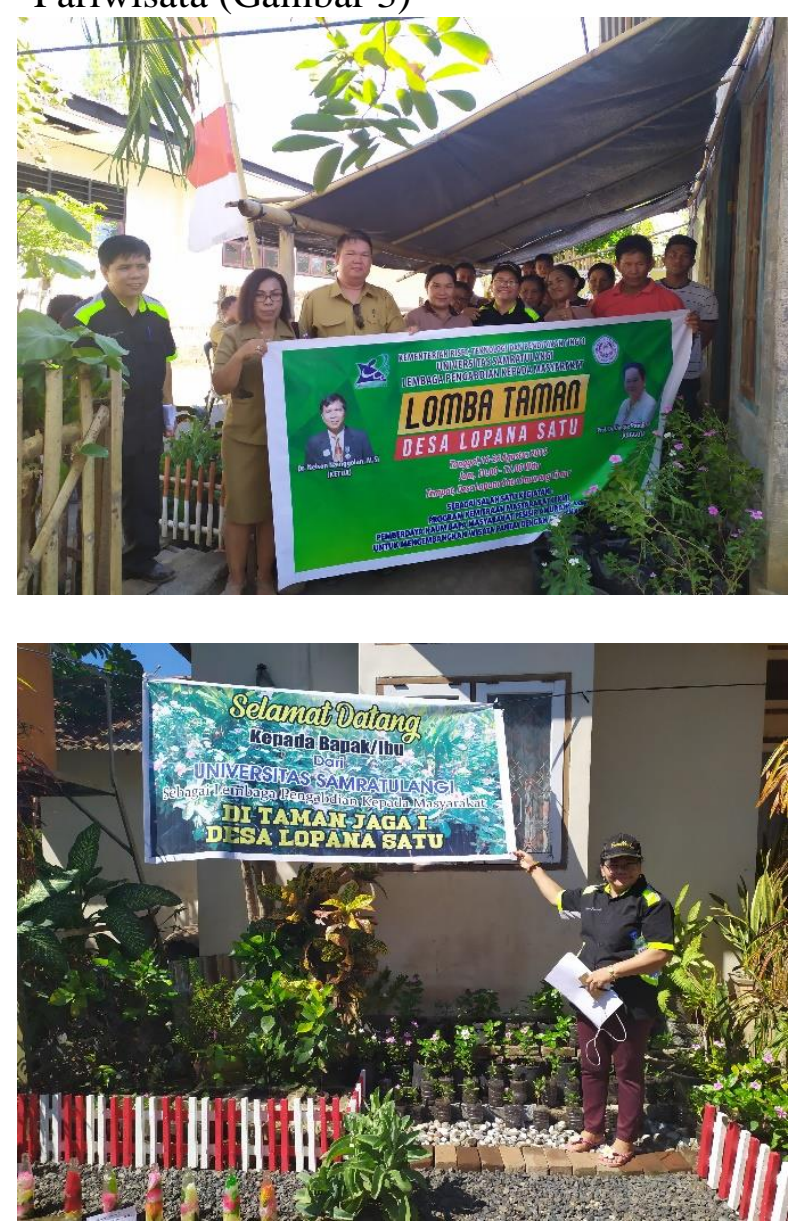

Gambar 3. Kegiatan Lomba Taman di desa Lopana Satu sebagai salah satu kegiatan PKM Pemberdayaan Kaum Bapa untuk desa wisata secara holistik.

Setelah perlombaan Taman juga dilakukan penyerahan Hadiah para juara dihadapan seluruh masyarakat dan tim pelaksana PKM dari LPPM Unsrat Manado yang dihadiri oleh sekitar 200 orang keseluruhan. Hadiah yang diberikan ada 5 yaitu Juara I, II, III, IV dan V serta juara terfavorit (Gambar 2).

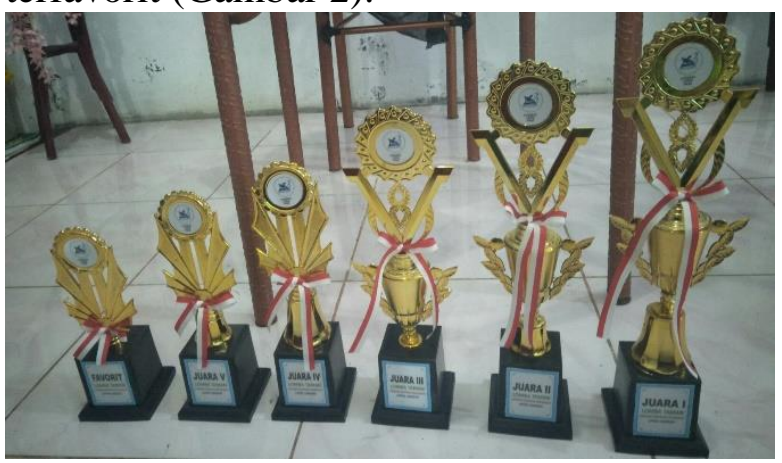

Gambar 2. Piala Kejuaraan Lomba Taman Lopana Satu

Pemberdayaan lainnya dilakukan juga secara pemenuhan mental dan rohani para Kaum Bapa melalui kegiatan pembinaan ke rohanian melalui kegiatan Seminar dan Kebagunan Rohani Pemberdayaan Kaum Bapa

\section{HASIL DAN PEMBAHASAN}

Kegiatan yang telah dilakukan dalam mencapai tujuan program kemitraan kepada masyarakat ini adalah sebagai berikut:

\section{Persiapan dan Koordinasi}

a. Mengurus surat izin dan surat tugas untuk melaksanakan kegiatan pengabdian pada masyarakat.

b. Koordinasi dengan Kepala Desa (Kuntua) beserta untuk menetapkan jumlah peserta dalam kegiatan program PKM ini. 
VIVABIO

Jurnal Pengabdian Multidisiplin

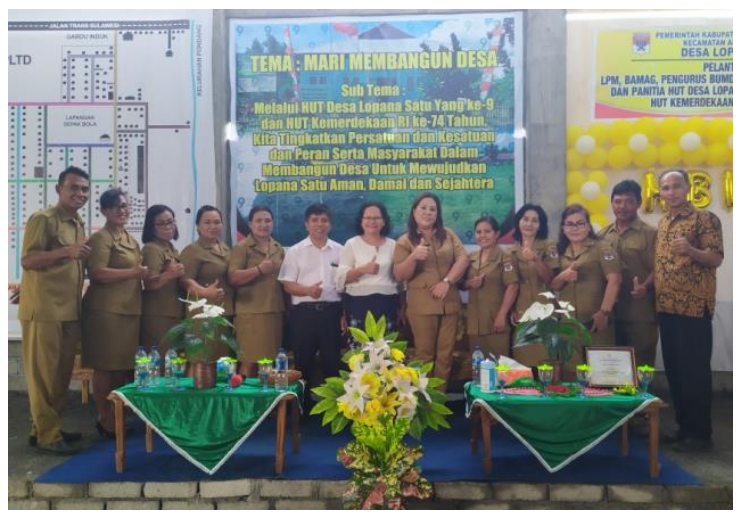

Gambar 1. Koordinasi dengan Hukum Tua Desa Lopana Satu beserta perangkat desa.

Kegiatan koordinasi dengan pemerintah Desa ini dilaksanakan dalam bentuk kegiatan sosialisasi program dan rencana kegiatan disesuaikan dengan kebutuhan desa pada April 2019 kepada Aparat Desa yang diikuti sekitar 20 orang. Sebagian perangkat Desa seperti Gambar 1.

\section{Pelaksanaan}

Kemudian dilakukan penyuluhan kepada masyarakat bersama apparat bersamaan dengan pelaksanaan pertandingan sepak bola antar jaga (lingkungan) dilakukan selama dua kali pertemuan dengan jumlah peserta adalah sekitar 100 orang bersama aparat Desa dan pelaksana kegiatan. Aparat yang sempat didokumentasikan adalah seperti pada Gambar 2, 3 dan 4 berikut ini.

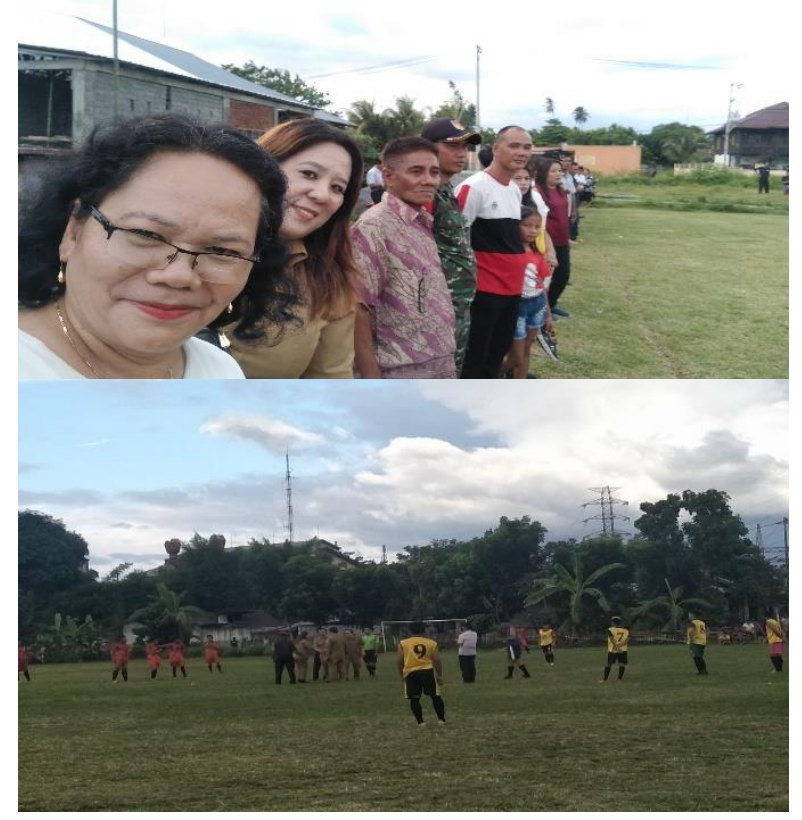

Gambar 2. Kebersamaan menonton Sepak Bola bersama Kuntua (Kepala Desa) Susanti Sumarah dan perangkat Desa sekaligus koordinasi pelaksanaan Program PKM.
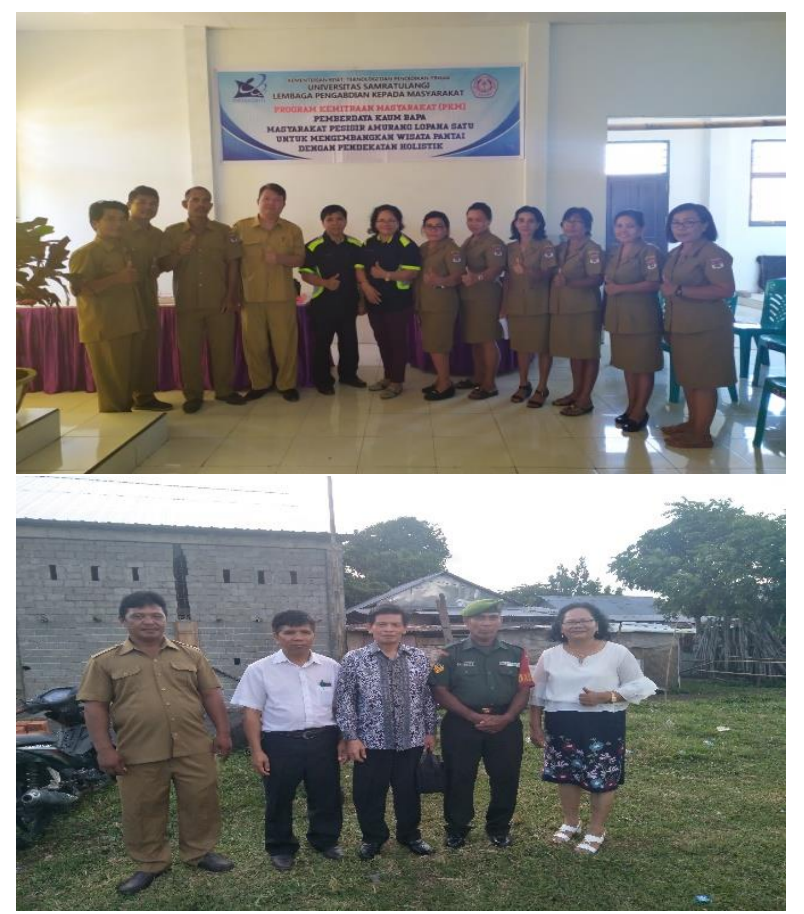

Gambar 3. Foto bersama pelaksana kegiatan dengan apparat Desa setelah pelaksanaan koordinasi pada Lomba Sepak Bola antar Jaga desa Lopana Satu.

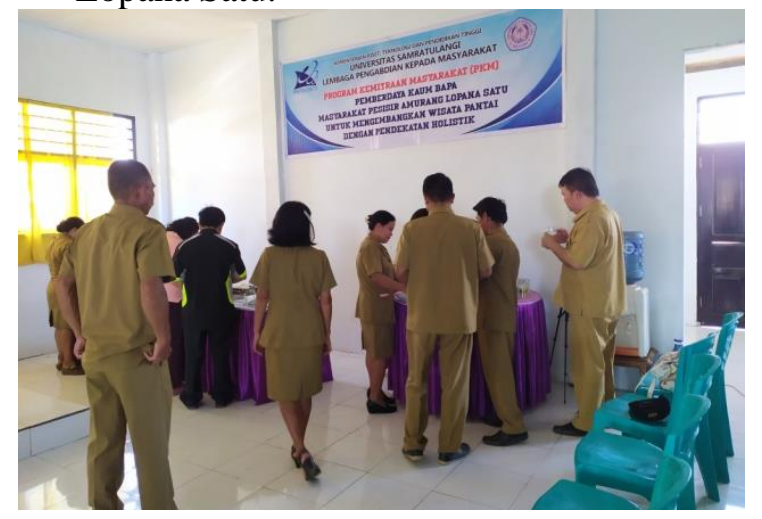

Gambar 4. Acara ramah-tamah (makan bersama) pada acara sosialisasi dan penyuluhan tentang konsep wisata pantai dan dampak ekonominya dalam sebagai salah satu kegiatan PKM pemberdayaan Kaum Bapa Desa Lopana Satu.

Pada tahap berikutnya pelaksanaan pengadaan bibit tanaman oleh pelaksana 


\section{VIVABIO}

Jurnal Pengabdian Multidisiplin

bekerjasama dengan PPSDA Manado dilaksanakan sekitar akhir Juni sampai Juli 2019. Tahap selanjutnya bibit tanaman hias dan buah-buahan serta pohon - pohonan diberikan kepada masyarakat Lopana Satu secara merata perjaga atau per lingkungan dengan rincian: Pohon Gaharu 20 polibag, Pala 35 polibag, Matoa 35 polibag, Durian 40 polibag, Duku 35 polibag dan tanaman hias tapak dara (Gambar 4 dan 5). Bibit diberikan kepada masyarakat Lopana Satu yang terdiri dari 8 jaga mulai Jaga I, II, III, IV, V, VI, VII dan VIII. Jadi jumlah bibit tanaman yang dibagikan keseluruhan adalah pohon Gaharu 160 polibag, Pala 280 polibag, Matoa 280 polibag, Durian 320 polibag, Duku 280 polibag dan tanaman hias tapak dara tidak dihitung tapi bebas sesuai kebutuhan masyarakat (Gambar 4 dan 5).

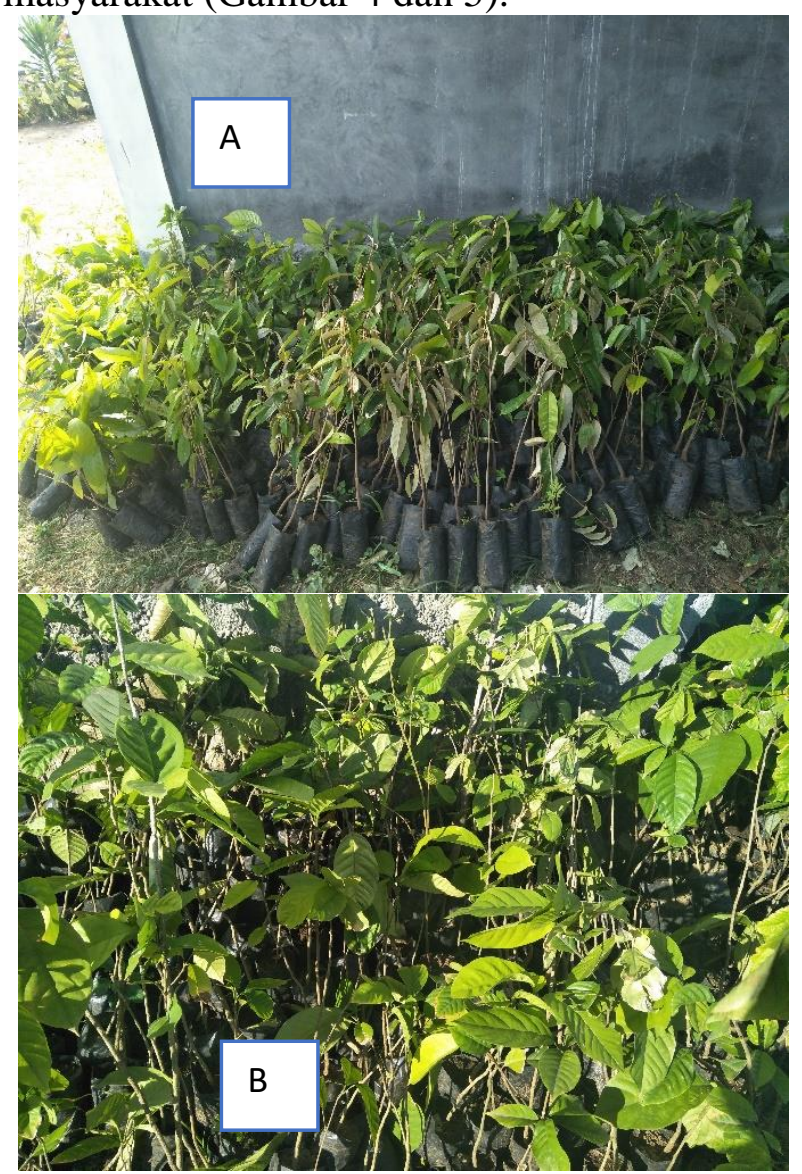

Gambar 4. Pembagian bibit kepada kepala Jaga atau Dusun untuk dibagikan kepada masyarakat perjaga yang di koordinir oleh pelaksana bersama Sekretaris Desa bapak Juffry Damogi dan Kuntua
Susanty Sumarah. A) Bibit durian dan dan Gaharu, B) bibit pala.

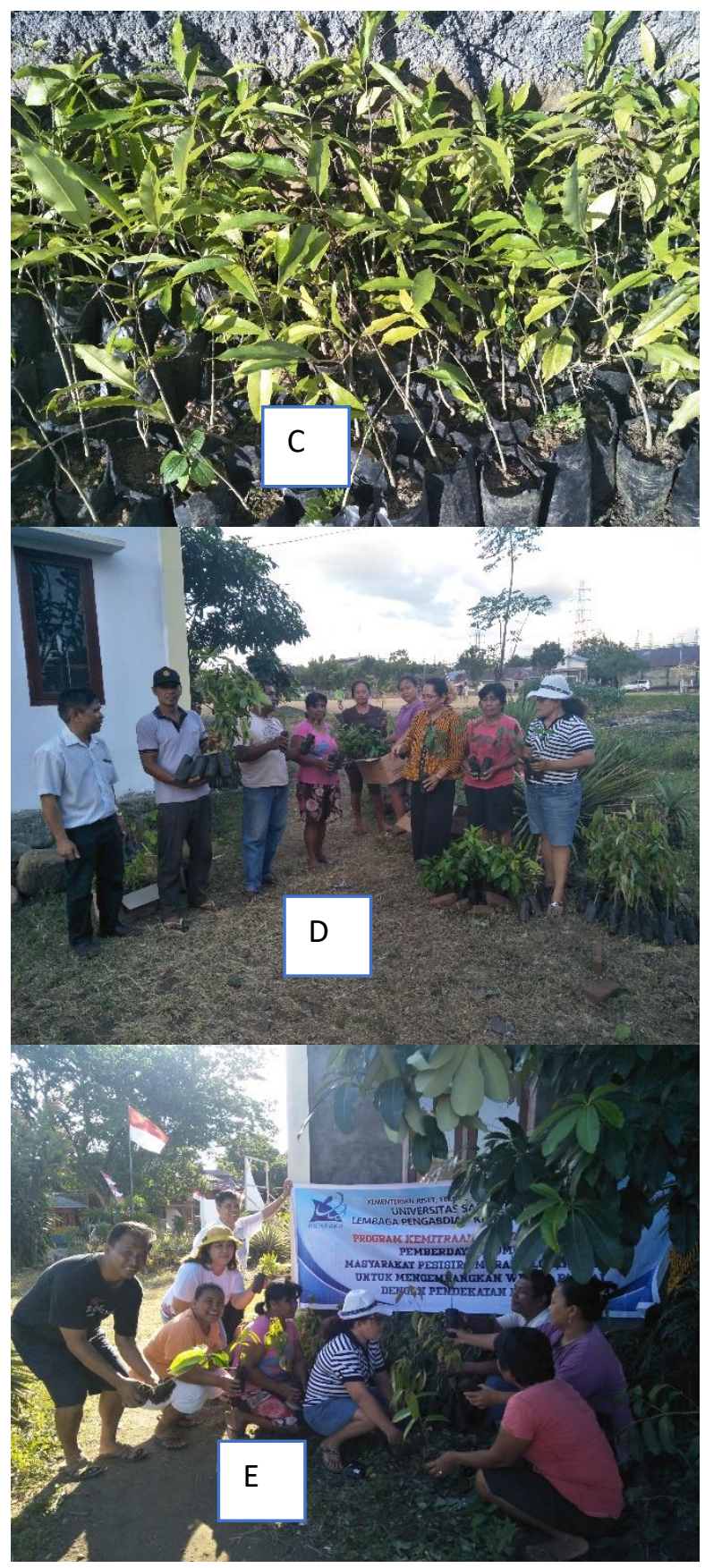

Gambar 5. Pembagian bibit kepada kepala Jaga atau Dusun untuk dibagikan kepada masyarakat perjaga C) bibit Gaharu, D) Kepala Jaga yang sudah mengambil bibit, E) Para Kepala Jaga sementara memilih dan menghitung bibit masing masing bagian yang di koordinir oleh pelaksana 


\section{VIVABIO}

Jurnal Pengabdian Multidisiplin

bersama Sekretaris Desa bapak Juffry Damogi dan Kuntua Susanty Sumarah

Bibit Tanaman yang dibagikan dipelihara dulu untuk adaptasi oleh karena Lopana Satu di daerah pantai yang siang hari udaranya panas. Selama adaptasi dilakukan penataan di lingkungan setiap jaga yang telah ditetapkan. Jumlah bibit tanaman yang bertahan tumbuh juga merupakan indikator kebersamaan dan motivasi setiap jaga pada penilaian lomba taman Lopana satu. Kegiatan ini dapat dilihat seperti pada Gambar 5, 6 dan 7.

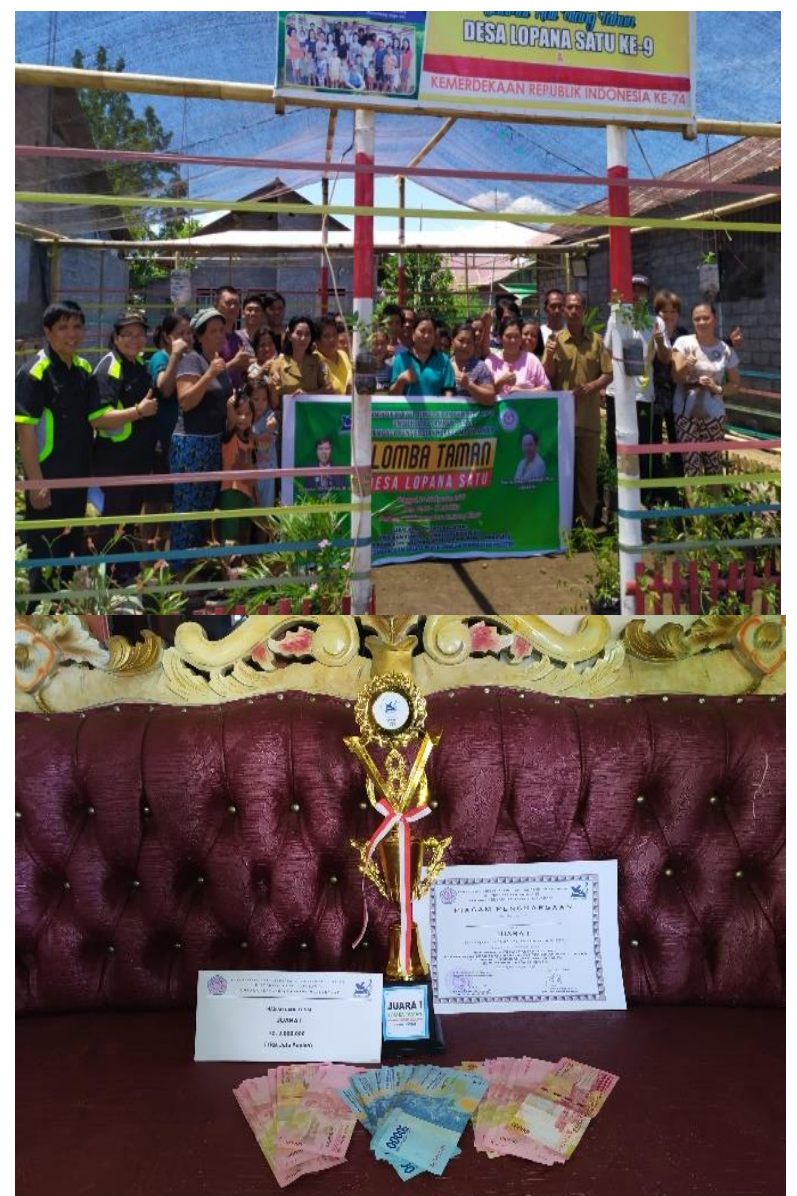

Gambar 5. Masyarakat Jaga VIII dan hadiah yang diberikan kepada Sang Juara I Lomba Taman Desa Lopana Satu dengan Pila dan Piagam penghargaan serta uang tunai 3 juta rupiah dengan nilai 399.
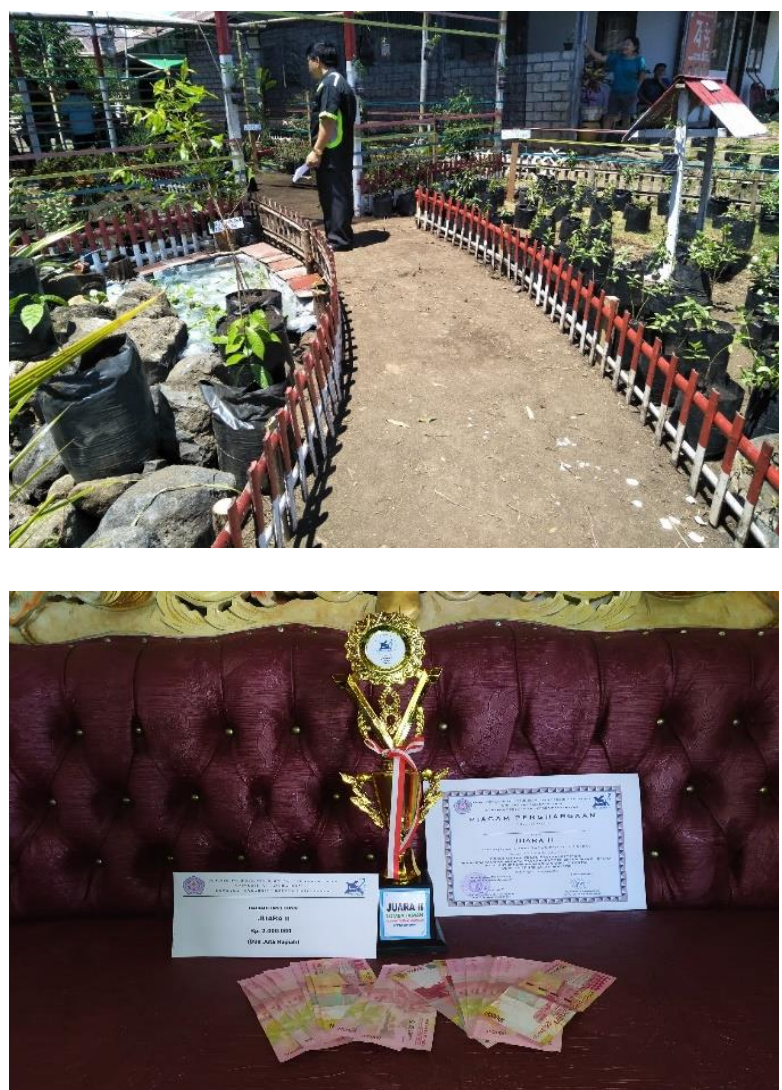

Gambar 6. Hadiah yang diberikan kepada Sang Juara II Lomba Taman Desa Lopana Satu dengan Pila dan Piagam penghargaan serta uang tunai 2 juta rupiah diraih oleh Jaga I dengan nilai 384 .

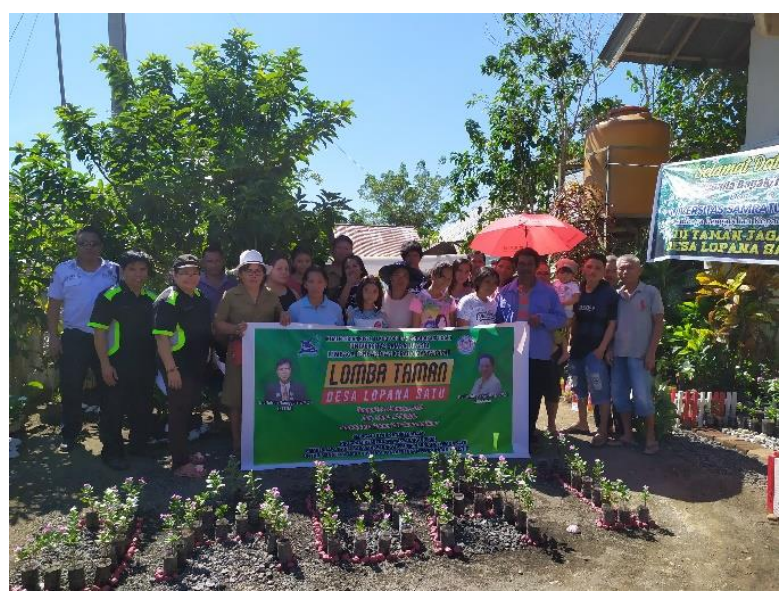

Gambar 7a. Foto bersama masyarakat Jaga I diakhir penilaian oleh para juri termasuk Juara ke III 
VIVABIO

Jurnal Pengabdian Multidisiplin

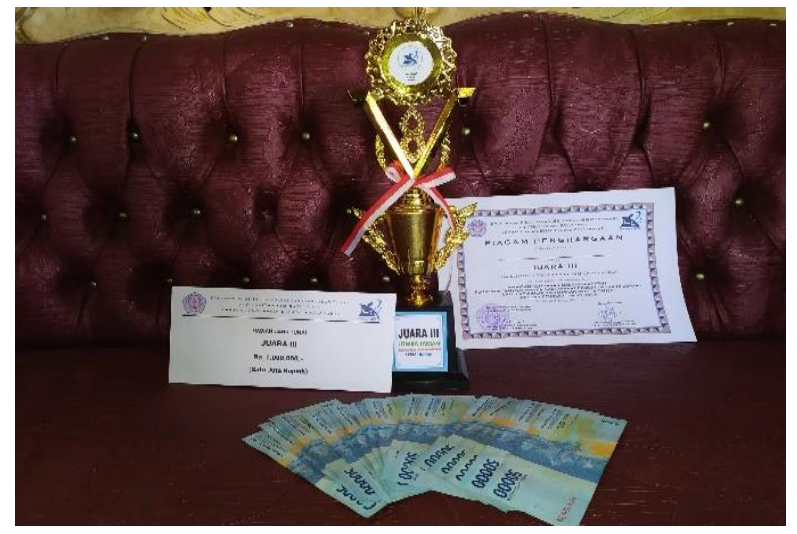

Gambar 7b. Masyarakat Jaga VI dan hadiah yang diberikan kepada Sang Juara III Lomba Taman Desa Lopana Satu dengan Piala dan Piagam Penghargaan serta uang tunai 1 juta rupiah dengan nilai 368

\section{Kegiatan Seminar Dan Kebangunan Rohani (Pendekatan Holistik)}

Kegiatan seminar dan kebangunan rohani dilakukan untuk merangkumkan seluruh kegiatan yang telah diterapkan kepada masyarakat Lopana Satu supaya berkelanjutan. Pada Seminar ini masyarakat dimotivasi atau didorong dengan pendekatan holistik melalui pendekatan perubahan pola pikir dan perubahan perilaku dari keacuhan terhadap kebahagiaan komunitas terkecilnya (keluarga) menjadi terbangkitkan rasa tanggungjawab, bahwa dirinya (Kaum Bapa) sangat menentukan kebahagiaan atau kesejahteraan keluarganya. Apabila keluargakeluarga di Desa bahagia maka terbentuklah Desa Sejahtera, Desa sejahtera akan memimbulkan daerag kabupaten dan provinsi sejahtera yang pada akhirnya bangsa dan negara sejahtera. Pembicara atau narasumber didatangkan ahlinya dari Bandung (Gambar 7 dan 8). Dilengkapi dengan Tim Pelayanan GPdI Khristos Sea Mitra Minahasa (Gambar 9)

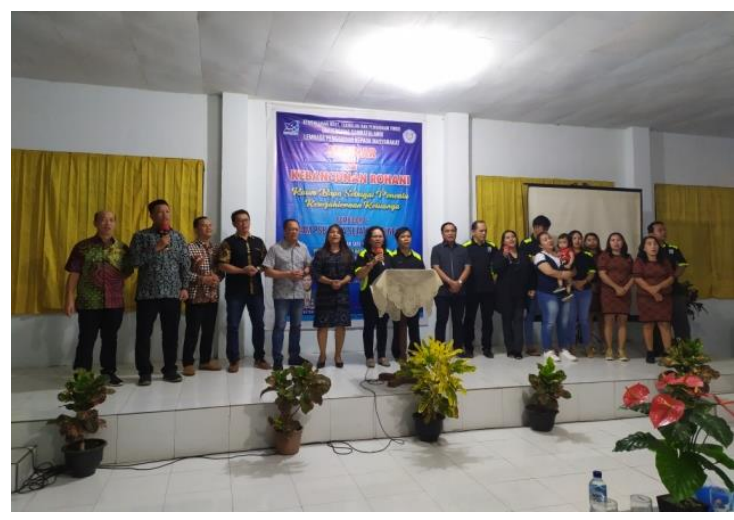

Gambar 2. Ketua pelaksana, anggota dan tim pembawa materi dari Pria Sejati Bersinergi dari Bandung, LPPM UNSRAT Manado dan GPdI Khristos Sea Mitra Minahasa

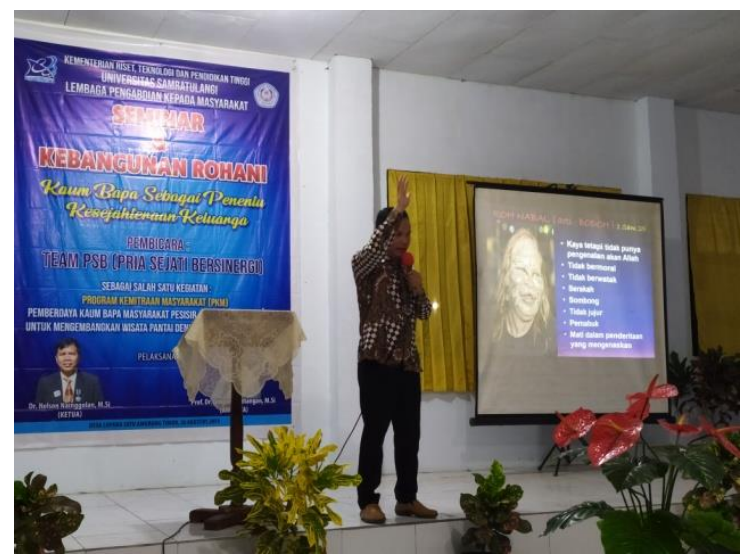

Gambar 3. Penyampaian materi oleh pembicara Pdt. Bisar Sagala dari salah satu dari team Pria Sejati Bersinergi dari 6 orang yang ada.

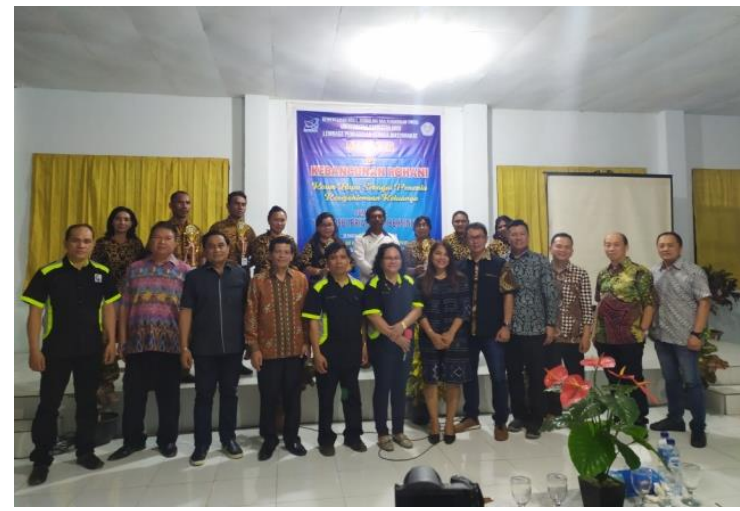

Gambar 4. Foto bersama pada saat pembrian hadiah kepada pemenang lomba taman. 


\section{VIVABIO}

Jurnal Pengabdian Multidisiplin

Bersama tim pelaksana PKM LPPM UNSRAT dengan Tim Pelayan Mimbar GPdI Khristos Sea Mitra dan Tim Pria Sejati Bersinergi dari Bandung.

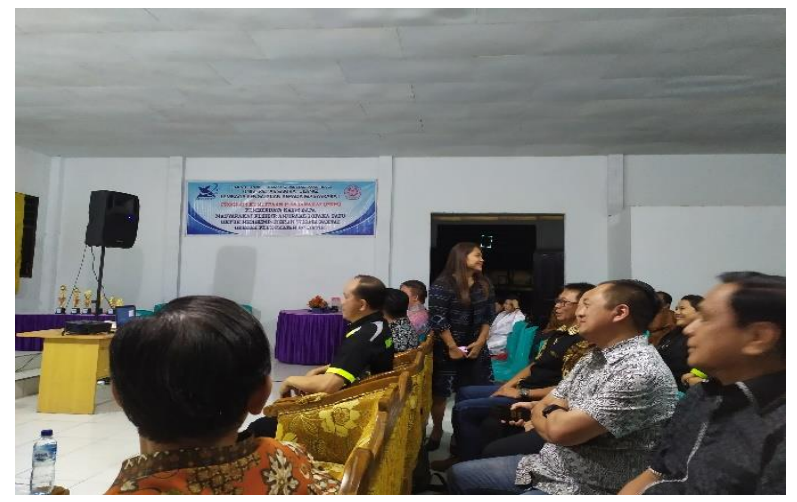

Gambar 10. Peserta Seminar dan Kebagunan Rohani pada kegiatan pemberdayaan holistik yang akan diterapkan di keluarga supaya harmonis dan sejahtera.

Berdasarkan pengamatan selama kegiatan pengabdian kepada masyarakat berlangsung, diperoleh beberapa hasil yang positif, diantaranya adalah:

1. Peserta menunjukkan antusias dan perhatian yang sangat tinggi terhadap materi yang disampaikan oleh tim pengabdian PKM LPPM Unrat dan Tim Pria Sejati Bersinergi sebagai pembicara.

2. Hal positif ditunjukkan oleh para peserta dengan melakukan ketika altarcall untuk di doakan hamper semua para Kaum Bapa maju kedepan panggung untuk didoakan dan didampingi untuk perubahan perilaku pada kehidupan selanjutnya.

3. Meningkatnya pengetahuan dan pemahaman para Kaum Bapa bahwa mereka (Kaum bapa) sangat menentukan kebahagiaan dan kesejateraan keluarganya. Mereka dengan kusuk meminta kepada Tuhan dalam doa supaya mereka mengalammi perubahan.

4. Meningkatnya kesadaran dan pentingnya Perilaku hidup dengan rasa tanggungjawab pada keluarga dan membangun hubungan yang utama antara suami istri yang harmonis dan saling menghargai yang selanjutnya akan dicontoh oleh anak anak dalam suatu komunitas terkecil keluarga.

5. Secara umum kegiatan pengabdian ini tidaklah menemukan kendala yang berarti.
Beberapa faktor yang mendukung terlaksananya kegiatan PKM ini adalah besarnya minat dan antusiasme Kepala Desa dan Sekretaris Desa mengarahkan para kepala jaga dan peserta selama kegiatan, sehingga kegiatan berlangsung dengan lancar dan efektif. Sedangkan faktor penghambatnya adalah musim kemarau atau panas yang terjadi selama pembibitan dan pemeliharaan sehingga bibit tanaman banyak yang mati setelah ditanam dan dijadikan taman hiasan .

\section{KESIMPULAN DAN SARAN}

Dari kegiatan PKM pemberdayaan Kaum Bapa Desa Lopana Satu untuk mengembangkan wisata pantai secara holistik sangat berdampak baik dilihat dari beberapa indikator- indikator yang menunjukkan antusias dan perhatian yang sangat tinggi terhadap program dan kegiatan yang disampaikan oleh tim pengabdian PKM LPPM Unrat dan Tim Pria Sejati Bersinergi sebagai pembicara. Kemudian adanya dampak positif ditunjukkan oleh para peserta dengan melakukan ketika altarcall untuk di doakan hampir semua para Kaum Bapa maju kedepan panggung memohonkan untuk didukung didoakan dan didampingi untuk perubahan perilaku pada kehidupan selanjutnya. Kemudian adanya peningkatan pengetahuan dan pemahaman para Kaum Bapa bahwa mereka (Kaum bapa) sangat menentukan kebahagiaan dan kesejateraan keluarganya. Mereka dengan kusuk meminta kepada Tuhan dalam doa supaya mereka mengalami perubahan setelah mengikuti seminar dan kebangunan rohani.

Hasil penyimpulan dan pengamatan masih diperlukan PKM lanjutan untuk mendampingi masyarakat untuk tetap bersemangat untuk melakukan dan memelihara taman dan fasilitas terkait untuk diwujudkan wisata pantai. Berharap kegiatan ini dilanjutkan pada tahun berikutnya.

\section{UCAPAN TERIMAKASIH}

Terimakasih diucapkan kepada: Kuntua dan Sekretaris Desa serta apparat terkait lainnya di Desa Lopana Satu Kec. Amurang Timur atas 
VIVABIO

Jurnal Pengabdian Multidisiplin

dukungan dan kerjasamanya untuk kegiatan PKM ini yang telah dilakukan. Kemudian terimakasih kepada Pemerintah Indonesia melalui Kemenristek Dikti atas bantuan pendanaan sesuai dengan SK no 8/E/KPT/2019 tanggal 19 Februari 2019. Kegiatan ini dapat berjalan berkat bantuan dari semua pihak yang tidak bisa disebut satu persatu.

\section{DAFTAR PUSTAKA}

Anonim. 2019. Proposal proyek
pengembangan wisata Tanjung
Papuma Jember http://bikelase.
blogspot.com/2014/11/proposal-
proyek-pengembangan-wisata.html
(akses 12 september 2019)

Pandiangan, D. 2018. Uji antidiabetes dan antikolesterol ektrak air C. roseus pad tikus jantan putih yang diberi lemak babi. Laporan PUU. LPPM Unsrat Manado

Pandiangan, D. Nainggolan, N., Maliangkay, H. Tumbol, M. 2018. The Potential Use of Catharanthus roseus as an Efective Herbal Medicine for Tourists. The article on 3rt International Conference Operation Research (ICOR) held in Manado, September 28th, 2018.

Pandiangan, D. Produksi Alkaloid secara In vitro. Unpad Press. Bandung

Pandiangan. D. dan Kandow. F.E. 2004. Inventarisasi dan Penapisan Alkaloid Tumbuhan Obat Tradisional Di Sangihe Di Sangihe Sulawesi Utara. Laporan Penelitian Dosen Muda DP2M DIKTI.

Peraturan Dirjen no P 01/IV-Set/2012. Tentang : Pedoman Penyusunan Rencana Karya Lima Tahun Dan R encana Karya Tahunan Usaha Peny ediaan Sarana Wisata Alam 2012. https://www.ekowisata.org/uploads/P 1_2012_PHKA_Lampiran.pdf (Akses 12 September 2019)
RIRN. 2016. Rencana Strategis Riset Nasional 2015-2045. Ristekdikti, Jakarta Indonesia.

Nuroh, E.Z. 2016. Pendekatan Holistik dan Kolaboratif dalam Pembelajaran Bahasa Inggris di Sekolah Dasar. Pedagogia vol 5 edisi $2: 264$ 